\title{
PENGARUH KANDUNGAN INFORMASI KOMPONEN LAPORAN ARUS KAS, LABA AKUNTANSI DAN SIZE PERUSAHAAN TERHADAP RETURN SAHAM PADA PERUSAHAAN CONSUMER GOOD DI BURSA EFEK INDONESIA
}

\author{
Laila Zulviana a \\ *abc Magister Manajemen, Fakultas Ekonomi dan Bisnis, Universitas Tanjungpura, \\ Pontianak \\ *Email : lailazulviana@student.untan.ac.id \\ (Diterima November 2019; Disetujui April 2020; Dipublikasikan Oktober 2020)
}

Abstrak

This study aims to examine the impact of the information content component of the cash flow statements, accounting profit, and company sizes on stock returns in consumer goods companies listed on the Indonesia Stock Exchange in the 2014-2017 period.

The population in this study are corporations listed on the Indonesia Stock Exchange, specifically consumer goods companies. The sample were obtain by purposive sampling method. There are 30 companies that match the criteria. The data analysis was contucted using SPSS version 22. The technique of data analysis was descriptive statistics, classic assumption tests, hypothesis testing utilising multiple linear regression analysis. The research findings explicated several discoveries such as the following : 1) Operating cah flow has a negative and no significant effect on stock return, 2) Investment cash flow holds a positive and not significant effect on stock return, 3) Funding cash flow have a positive and not significant on effect stock return, 4) Accounting profit has a negative and no significant on effect return stock, 5) The size of the company has a positive and significant effect on stock return.

The limitations of this study were that the adjusted R2 examined only had an effect of $13.2 \%$. This shows that the influence of operating cash flows, investment cash flows, funding cash flows, accounting profit and company size on stock return is still very small compared to other factor, which is $\mathbf{8 6 . 8 \%}$ and influenced by other factors which can be examined further. Future research needs to pay attention to other factors such as grofit, ROA and ROE.

Keyword : operating cash flow, investment cash flow, funding cash flow, accounting profit, company size, and stock return.

\section{LATAR BELAKANG}

Suatu pasar modal yang kompetitif, terbentuknya harga ekuilibrium suatu aktiva atau sekuritas ditentukan oleh penawaran dan permintaan. Harga ekuilibrium ini mencerminkan konsensus bersama antara semua partisipan pasar tentang nilai dari aktiva tersebut berdasarkan informasi yang tersedia. Harga ekuilibrium tersebut akan bergeser ke ekuilibrium yang baru, bila muncul informasi baru yang relevan yang digunakan untuk menganalisis dan menentukan harga aktiva tersebut. Meskipun informasi akuntansi bukan merupakan satu-satunya informasi yang menjadi dasar pertimbangan membeli atau menjual saham, namun penyampaian informasi 
PENGARUH KANDUNGAN INFORMASI KOMPONEN LAPORAN ARUS KAS, LABA AKUNTANSI DAN SIZE PERUSAHAAN TERHADAP RETURN SAHAM PADA PERUSAHAAN CONSUMER GOOD DI BURSA EFEK INDONESIA

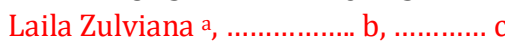

tersebut dimaksudkan untuk mengurangi ketidakpastian investasi. Pasar modal memiliki sejumlah sifat khas apabila dibandingkan dengan pasar yang lain (Suhairi,2006).

Penelitian mengenai adanya pengaruh arus kas terhadap return saham antara lain telah dilakukan oleh Rachmawati (2016), Purwanti, Masitoh, Chamsatu (2014) dan Hertsediandani (2017). Penelitian-penelitian tersebut berhasil membuktikan bahwa kandungan informasi arus kas merupakan salah satu informasi penting dalam mempengaruhi keputusan investasi.

Penelitian mengenai adanya pengaruh size perusahaan terhadap return saham telah dilakukan oleh I Made Gunartha Dwi Putra dan I Made Dana (2015). Penelitian tersebut berhasil membuktikan bahwa kandungan Informasi size perusahaan merupakan salah satu informasi penting dalam mempengaruhi keputusan investasi.

Permasalahan dalam penelitian ini adalah : 1). Bagaimana pengaruh arus kas operasi terhadap return saham pada perusahaan consumer goods ? 2). Bagaimana pengaruh arus kas investasi terhadap return saham pada perusahaan consumer goods ? 3). Bagaimana pengaruh arus kas pendanaan terhadap return saham pada perusahaan consumer goods ? 4). Bagaimana pengaruh laba akuntansi terhadap return saham pada perusahaan consumer goods ? 5). Bagaimana pengaruh size perusahaan terhadap return saham pada perusahaan consumer goods?

Tujuan penelitian ini yaitu : 1) Menguji dan mengetahui pengaruh arus kas operasi terhadap return saham pada perusahaan consumer goods. 2) Menguji dan mengetahui pengaruh arus kas investasi terhadap return saham pada perusahaan consumer goods. 3) Menguji dan mengetahui pengaruh arus kas pendanaan terhadap return saham pada perusahaan consumer goods. 4) Menguji dan mengetahui pengaruh laba akuntansi terhadap return saham pada perusahaan consumer goods. 5) Menguji dan mengetahui pengaruh size perusahaan terhadap return saham pada perusahaan consumer goods. Kebaharuan dalam penelitian ini pada perusahaan consumer goods yang terdaftar di BEI tahun periode 2014 -2017.

\section{KAJIAN LITERATUR}

Menurut teori sinyal, perusahaan menyampaikan informasi ke pasar modal yang berupa laporan keuangan dan mampu ditangkap oleh pasar modal sebagai suatu informasi yang menggambarkan kinerja perusahaan sehingga dapat memberikan refrensi terhadap calon investor untuk menilai kinerja perusahaan dimasa depan Teori sinyal ini merupakan dasar peneliti untuk meneliti bagaimana sikap perusahaan dalam keberhasilan atau kegagalannya dalam operasional perusahaan kepada pemilik modal. 
Aktivitas operasi adalah aktivitas penghasil utama pendapatan perusahaan dan aktiva lain yang bukan merupakan aktivasi investasi dan pendanaan, umumnya berasal dari transaksi dan peristiwa lain yang mempengaruhi penetapan laba atau rugi, dan merupakan indikator yang menentukan apakah operasi perusahaan dapat dapat menghasilkan kas yang cukup untuk melunasi pinjaman, memelihara kemampuan operasi perusahaan, membayar dividen dan melakukan investasi baru tanpa menghandalkan pada sumber pendanaan. Arus kas operasi adalah selisih bersih antara penerimaan dan pengeluaran kas dan setara kas yang berasal dari aktivitas operasi selama satu tahun buku, sebagaimana dalam laporan arus kas.

Aktivitas investasi adalah aktivitas yang menyangkut perolehan atau pelepasan aktiva jangka panjang (aktiva tidak lancar) serta investasi lain yang tidak termasuk dalam setara kas, mencakup aktivitas meminjamkan uang dan mengumpulkan piutang tersebut serta memperoleh dan menjual investasi dan aktiva jangka panjang yang produktif.

Arus kas yang timbul dari aktivitas pendanaan perlu dilakukan pengungkapan terpisah karena berguna untuk memprediksi klaim terhadap arus kas masa depan oleh para pemasok modal perusahaan. Mackenzie, et al (2012) menjelaskan aktivitas pendanaan adalah aktivitas yang mengakibatkan perubahan dalam besaran atau ukuran dari komposisi ekuitas yang dikontribusikan dan pinjaman dari suatu entitas. Klasifikasi ini biasanya terdiri dari semua arus kas yang disebabkan dari mutasi semua akun hutang jangka panjang, dan akun ekuitas dari suatu entitas. Aktivitas pendanaan adalah transaksi dan kejadian dimana kas diperoleh dari dan dibayarkan kembeli kepada para pemilik dan kreditor.

Laba merupakan informasi perusahaan yang paling diminati dalam pasar uang. Samsul (2006) menyatakan maju mundurnya suatu perusahaan tercemin dari keuntungan yang diperoleh setiap tahunnya mengindikasi suatu kemajuan namun jika menderita kerugiaan setiap tahunnya mengindikasikan kebangkrutan. Dalam laporan laba rugi komrehensif tercermin laba kotor, laba operasi dan laba bersih. Laba atau laba bersih mengidentifikasikan profitabilitas perusahaan, laba mencerminkan pengembalian kepada pemegang ekuitas untuk periode bersangkutan.

Menurut Tandelilin (2010) mendefinisikan return saham adalah pendapatan atau imbalan yang berasal dari dana yang diinvestasikan dalam bentuk saham pada perusahaan yang diberikan kepada investor. Salah satu faktor yang memotivasi para investor dalam berinvestasi adalah tingkat return yang akan didapatkannya ketika menanamkan modalnya pada emiten tanpa melupakan resiko yang harus dihadapinya. Semakin tinggi perubahan harga saham maka semakin tinggi return yang dihasilkan. 
PENGARUH KANDUNGAN INFORMASI KOMPONEN LAPORAN ARUS KAS, LABA AKUNTANSI DAN SIZE PERUSAHAAN TERHADAP RETURN SAHAM PADA PERUSAHAAN CONSUMER GOOD

Return saham dapat dapat dihitung dengan menggunakan rumus sebagai berikut (Yocelyn dan Christiawan 2012):

$$
R_{t . t}=\left[\frac{p_{i} . t-p_{i}(t-1)}{p_{i}(t-1)}\right] \times 100 \%
$$

Keterangan :

Rit = tingkat return saham perusahaan i pada periode $\mathrm{t}$

Pit = harga saham perusahaan i pada periode $\mathrm{t}$

$\operatorname{Pi}(\mathrm{t}-1)=$ harga saham perusahaan i pada peeriode $\mathrm{t}-1$.

Berikut ini gambaran kerangka penelitian ini :

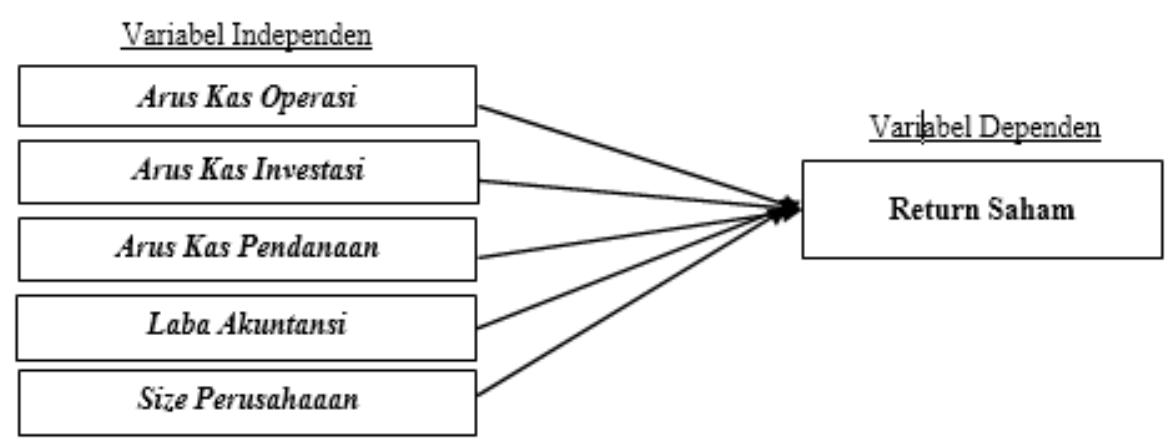

Sumber : Data Olaha

Gambar Kerangka Konseptual

\section{Pengaruh Arus Kas Operasi Terhadap Return Saham}

Arus kas aktivitas operasi diperoleh dari aktivitas penghasil utama pendapatan saham. Sehingga pada umumnya arus kas operasi berasal dari transaksi yang mempengaruhi laba atau rugi perusahaan. Secara teori, semakin tinggi arus kas operasional perusahaan maka semakin tinggi kepercayaan investor pada perusahaan tersebut, dan mengakibatkan semakin besar nilai expected return saham, Sebaliknya, jika semakin rendah arus kas operasi perusahaan maka semakin kecil kepercayaan investor yang mengakibatkan semakin rendahnya nilai expected return saham. Hasil penelitian yang dilakukan oleh Gilbert Ayub Tumbel, Jantje Tinangon, dan Stanley Kho Walandouw (2016) menyatakan bahwa arus kas operasi berpengaruh secara signifikan terhadap return saham. Sedangkan hasil 
PENGARUH KANDUNGAN INFORMASI KOMPONEN LAPORAN ARUS KAS, LABA AKUNTANSI DAN SIZE PERUSAHAAN TERHADAP RETURN SAHAM PADA PERUSAHAAN CONSUMER GOOD DI BURSA EFEK INDONESIA

Laila Zulviana a ,................ b, ............ C

penelitian dari Adiwiratama (2012) tidak berhasil membuktikan bahwa arus kas operasi berpengaruh secara signifikan terhadap return saham.

Berdasarkan adanya penelitian yang telah dilakukan sebelumnya, maka dirumuskan hipotesis sebagai berikut :

H1 : Arus kas operasi berpengaruh signifikan terhadap return saham.

H2: Arus kas operasi berpengaruh signifikan terhadap return saham

H3 : Arus kas pendanaan berpengaruh signifikan terhadap return saham.

H4 : Laba Akuntansi berpengaruh signifikan terhadap return saham.

H5 : Size perusahaan berpengaruh signifikan terhadap return saham.

\section{Metode Penelitian}

Jenis penelitian ini menggunakan penelitian kuantitatif yaitu suatu analisis data yang diperoleh dari daftar pertanyaan yang telah diolah ke dalam bentuk angkaangka dan pembahasannya melalui perhitungan statistik. Penelitian ini dilakukan pada Perusahaan Consumer Good yang terdaftar di Bursa Efek Indonesia periode 2014-2017. Data diambil melalui situs resmi Bursa Efek Indonesia pada website www.idx.co.id.

Populasi dalam penelitian ini adalah perusahaan consumer goods yang terdaftar di Bursa Efek Indonesia periode 2014-2017. Sejumlah 30 perusahaan akan dipilih dari 50 perusahaan yang tercatat di BEI akan digunakan sebagai sampel dalam penelitian. Dan Sampel yang digunakan dalam penelitian ini dengan menggunakan teknik purposive sampling,yaitu teknik penentuan sampel dengan pertimbangan tertentu. Adapun pertimbangan tertentu sebagai berikut :

a. Perusahaan consumer goods yang terdaftar di Bursa Efek Indonesia Periode tahun 2014-2017.

b. Perusahaan yang menyertakan laporan arus kas dan laporan laba rugi dalam pelaporan keuangan tahun 2014-2017

c. Perusahaan consumer goods yang sahamnya aktif diperdagangkan di BEI

Beberapa variabel yang digunakan dan pengukurnya sebagai berikut :

1. Variabel arus kas operasi diukur dengan persentase perubahan arus kas yang dihitung dari persentase perubahan arus kas aktivitas operasi sekarang ( $\mathrm{t}$ ) dikurangi kas yang diperoleh dari kegiatan operasional periode tahun sebelumnya ( $\mathrm{t}-1)$ dibagi dengan kas yang diperoleh dari kegiatan operasional periode tahun sebelumnya ( $\mathrm{t}-1)$ atau dihitung dengan rumus sebagai berikut (Yocelyn dan Christiawan 2012) : 


$$
\Delta A K O=\left[\frac{A K O(t)-A K O(t-1)}{A K O(t-1)}\right] \times 100 \%
$$

Keterangan :

${ }^{\triangle}$ AKO $=$ Perubahan arus aktivitas operasi

$A K O_{010} \quad=$ Arus kas operasi periode tersebut

$A K O M)=$ Arus Kas Operasi dari periode sebelumnya

2. Variabel arus kas dari aktivitas investasi diukur dengan persentase perubahan arus kas yang dihitung dari persentase perubahan arus kas dari aktivitas investasi sekarang ( $\mathrm{t}$ ) dikurangi diperoleh dari kegiatan investasi periode tahun sebelumnya ( $\mathrm{t}-1$ ) dibagi dengan kas yang diperoleh dari kegiatan investasi periode tahun sebelumnya ( $t-1)$ atau dihitung dengan rumus sebagai berikut (Yocely dan Christiawan 2012):

$$
\Delta \operatorname{AKI}=\left[\frac{\operatorname{AKI}(t)-\operatorname{AKI}(t-1)}{\operatorname{AKI}(t-1)}\right] \times 100 \%
$$

Keterangan :

$\triangle_{\text {AKI }}=$ Perubahan arus kas investasi

$\mathrm{AKI}_{\text {(i) }} \quad=$ Arus kas investasi periode tersebut

$A K I_{(0+1)}=$ Arus kas inestas dari periode sebelumnya

3. Variabel arus kas dari aktivitas pendanaan diukur dengan persentase perubahan arus kas yang dihitung dari persentase perubahan arus kas dari aktivitas pendanaan sekarang $(\mathrm{t})$ dikurangi diperoleh dari kegiatan pendanaan periode tahun sebelumnya ( $\mathrm{t}-1)$ dibagi dengan kas yang diperoleh dari kegiatan pendanaan periode tahun sebelumnya ( $\mathrm{t}-1)$ atau dihitung dengan rumus sebagai berikut (Yocelyn dan Christiawan 2012):

$$
\Delta A K P=\left[\frac{\operatorname{AKP}(t)-\operatorname{AKP}(t-1)}{\operatorname{AKP}(t-1)}\right] \times 100 \%
$$

Keterangan :

$$
\begin{array}{ll}
\Delta_{\text {AKP }} & =\text { Perubahan arus kas pendanaan } \\
\operatorname{AKP}(t) & =\text { Arus kas pendanaan periode tersebut } \\
\text { AKP }(t+1) & =\text { Arus kas pendanaan dari periode sebelumnya }
\end{array}
$$

4. Variabel laba akuntansi diukur dengan persentase perubahan laba yang dihitung dari persentase perubahan laba akuntansi sekarang $(\mathrm{t})$ dikurangi laba akuntansi periode tahun sebelumnya (t-1) dibagi dengan laba 
PENGARUH KANDUNGAN INFORMASI KOMPONEN LAPORAN ARUS KAS, LABA AKUNTANSI DAN SIZE PERUSAHAAN TERHADAP RETURN SAHAM PADA PERUSAHAAN CONSUMER GOOD DI BURSA EFEK INDONESIA

Laila Zulviana a, ................ b, ........... c

akuntansi periode tahun sebelumnya ( $\mathrm{t}-1)$ atau diukur dengan rumus sebagai berikut (Yocelyn dan Christiawan 2012):

$\triangle$ Laba Akuntansi

$$
=\left[\frac{\text { Laba Akuntansi }(t)-\text { Laba AKuntansi }(t-1)}{\text { Laba Akuntansi }(t-1)}\right] \times 100 \%
$$

Keterangan :

${ }^{\Delta}$ Laba Akuntansi = Perubahan laba akuntansi

Laba akuntansi (c) = Laba akuntansi periode tersebut

Laba akuntansi $($ (-1) $)$ = Laba akuntansi periode sebelumnya|

5. Size perusahaan merupakan skala berapa besar yang ditentukan oleh beberapa hal antara lain total dari penjualan dan total dari harta (aktiva). besarnya perusahaan yang ditentukan oleh beberapa hal antara lain total dari penjualan dan total dari harta (aktiva). Variabel ini diukur dengan menggunakan logaritma natural dari total penjualan pada akhir tahun (Chan et al, 2005) :

\section{Ukuran Perusahaan $=$ Ln of Total Sales}

6. Variabel return saham yang diukur dengan mengurangi harga saham waktu tertentu dengan harga saham sebelumnya dibagi dengan harga saham periode sebelumnya atau dihitung dengan rumus sebagai berikut : (Hermanungsih, 2012):

$$
R_{1 . t}=\left[\frac{p_{i . t}-p_{i}(t-1)}{p_{i}(t-1)}\right] \times 100 \%
$$

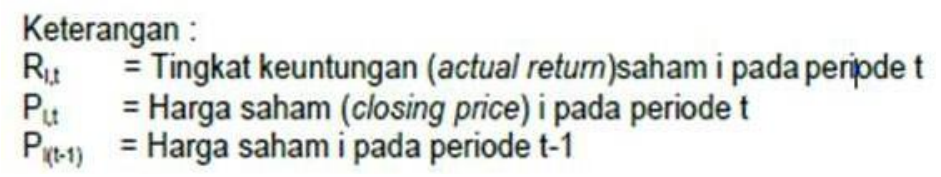

Teknik analisis data yang digunakan dalam penelitian ini adalah analisis linier berganda. Dimana dalam analisis regresi linier berganda data yang diolah harus bebas dari uji asumsi klasik. Pengujian asumsi klasik ini dilakukan agar variabel independennya dinyatakan valid dimana pengujian asusmsi klasik terdiri atas uji asumsi normalitas,autokorelasi,multikolininearitas dan heterokedastisitas.

Model analisis yang digunakan adalah untuk melakukan pengujian ini adalah metode analisis regresi linear berganda. Regresi linear berganda digunakan untuk mengukur pengaruh antara lebih dari satu variabel indepanden terhadap variabel dependen. Rumus persamaan Regresi Linear Berganda menurut Sugiyono (2009) adalah sebagai berikut:

$\mathrm{RS}=\alpha+\mathrm{b} 1 \mathrm{AKO}+\mathrm{b} 2 \mathrm{AKI}+\mathrm{b3} \mathrm{AKP}+\mathrm{b} 4 \mathrm{LA}+\mathrm{b} 5 \mathrm{SP}+$ ?

*corresponding authors e-mail : lailazulviana@student.untan.ac.id Online ISSN: 2721-4230 | Print ISSN: 2721-4281 
PENGARUH KANDUNGAN INFORMASI KOMPONEN LAPORAN ARUS KAS, LABA AKUNTANSI DAN SIZE PERUSAHAAN TERHADAP RETURN SAHAM PADA PERUSAHAAN CONSUMER GOOD DI BURSA EFEK INDONESIA

Laila Zulviana a, ................ b, ........... c

Pengujian hipotesis dalam penelitian ini menggunakan uji koefisien determinan (adjusted R2), uji signifikansi simulan (uji statistik F ), dan uji signifikan parameter individual (uji statistik t ).

\section{HASIL PENELITIAN DAN PEMBAHASAN}

Objek penelitian ini adalah perusahaan consumer goods. Perusahaan consumer goods terdiri dari 5 sub sektor, yakni :

1. Sub sektor makanan dan minuman terdiri dari perusahaan : PT. Tiga Pilar Sejahtera Tbk, PT. Wilmar Cahaya Indonesia Tbk, PT. Ultrjaya Milk Industry dan Tranding Co Tbk, PT. Siantar Top Tbk, PT. Sekar Bumi Tbk, PT. Nippon Indosari Corpinda Tbk, PT. Mayora Indah Tbk, PT. Sekar Laut Tbk, PT. Prasidha Aneka Niaga Tbk dan PT. Tri Bayan Tirta Tbk.

2. Sub sektor rokok terdiri dari perusahaan : PT. Gudang Garam Tbk, PT.Hanjaya Mandala Sampoerna Tbk, dan PT. Wismilak Inti Makmur Tbk.

3. Sub sektor farmasi terdiri sari perusahaan : PT. Taiso Pharmaceutical Tbk, PT. Pyridam Farma Tbk, PT. Kalbe Farma Tbk, PT. Kimia Farma Tbk, PT. Darya Varia Laboratoria Tbk, PT. Industri Jamu dan Farmasi Sido Muncul Tbk, PT. Indofarma Tbk dan PT. Merck Tbk.

4. Sub sektor kosmetik dan barang keperluan rumah tangga terdiri dari perusahaan : PT. Unilever Indonesia Tbk, PT. Akasha Wira International Tbk, PT. Martina Berto Tbk, dan PT. Mandom Indonesia Tbk.

5. Sub sektor peralatan rumah tangga terdiri dari perusahaan : PT. Langgeng Makmur Industri Tbk, PT. Kedaung Indah Can Tbk, dan PT. Chitose International Tbk. dan PT. Kedawung Setia Industri Tbk.

Statistik deskriptif digunakan untuk melihat distribusi data dari data keuangan perusahaan sampel yang digunakan dalam penelitian. Berikut ini statistik deskriptif dari masing-masing variabel penelitian :

Tabel

Statistik Deskriptif

\begin{tabular}{|l|r|r|r|r|r|}
\hline & $\mathrm{N}$ & Minimum & Maximum & Mean & Std. Deviation \\
\hline SP & 120 & 3.19 & 9.33 & 4.8538 & 10.97517 \\
RS & 120 & 3.20 & 9.96 & 6.1023 & 12.66866 \\
LA & 120 & 3.31 & 10.00 & 6.6231 & 12.77245 \\
AKO & 120 & -2.48 & 10.00 & -6.9053 & 12.89327 \\
AKI & 120 & -3.59 & 9.99 & -7.5149 & 14.66054 \\
AKP & 120 & -3.84 & 9.99 & -7.6137 & 14.78442 \\
Valid N (listwise) & 120 & & & & \\
\hline
\end{tabular}

Sumber : Hasil Olahan SPSS (2018)

*corresponding authors e-mail : lailazulviana@student.untan.ac.id Online ISSN: 2721-4230 | Print ISSN: 2721-4281 
PENGARUH KANDUNGAN INFORMASI KOMPONEN LAPORAN ARUS KAS, LABA AKUNTANSI DAN SIZE PERUSAHAAN TERHADAP RETURN SAHAM PADA PERUSAHAAN CONSUMER GOOD

DI BURSA EFEK INDONESIA

Laila Zulviana a , ................. b, ............ c

\section{Uji Asumsi Klasik}

Tabel Hasil Uji Normalitas

\begin{tabular}{|ll|r|}
\hline & & $\begin{array}{c}\text { Unstandardi } \\
\text { zed } \\
\text { Residual }\end{array}$ \\
\hline$N$ & 120 \\
Normal Parametersa,b & Mean & .0000000 \\
& Std. Deviation & 1.52177947 \\
Most Extreme & Absolute & .058 \\
Differences & Positive & .058 \\
& Negative & -.035 \\
Test Statistic & .058 \\
Asymp. Sig. (2-tailed) & $.200^{\mathrm{c}, \mathrm{d}}$ \\
\hline
\end{tabular}

a. Test distribution is Normal.

b. Calculated from data.

Sumber : Hasil Olahan SPSS (2018)

Berdasarkan hasil uji normalitas diketahui nilai signifikannya 0,200 $>0,05$, ini menunjukan bahwa data yang diteliti memiliki kriteria asumsi normalitas. Data yang memenuhi kriteria berarti data ini berdistribusi normal sehingga data ini dapat dilanjutkan dengan uji hipotesis penelitian.

Tabel Hasil Uji Autokorelasi

\begin{tabular}{|l|r|r|r|r|r|}
\hline Model & $\mathrm{R}$ & R Square & $\begin{array}{c}\text { Adjusted R } \\
\text { Square }\end{array}$ & $\begin{array}{c}\text { Std. Error of the } \\
\text { Estimate }\end{array}$ & Durbin-Watson \\
\hline 1 & $.420^{\mathrm{a}}$ & .176 & .140 & 1.51883 & 2.015 \\
\hline
\end{tabular}

Sumber : Hasil Olahan SPSS (2018)

Berdasarkan tabel di atas nilai DW sebesar 2,015 sedangkan pada tabel DW dengan signifikansinya 0,05 dan jumlah data $(n)=120$ serta jumlah variabel independen $(\mathrm{k})=5$ diperoleh nilai DU sebesar 2,2104. Karena nilai DW menunjukan angka 2,015, dimana angka tersebut berada diantara du $<\mathrm{d}<4$-du $=(1,789<2,015<$ 2,2104 ), maka hipotesis nol (H0) diterima berarti tidak terjadi autokorelasi yang artinya data ini dapat dilanjutkan dengan uji hipotesis penelitian.

Tabel Hasil Uji Multikolinieritas

\begin{tabular}{|c|c|c|c|c|c|c|c|c|}
\hline \multirow{2}{*}{\multicolumn{2}{|c|}{ Model }} & \multicolumn{2}{|c|}{ Unstandardized Coefficients } & \multirow{2}{*}{$\begin{array}{c}\text { Standardized } \\
\text { Coefficients }\end{array}$} & \multirow[b]{2}{*}{$\mathrm{T}$} & \multirow[b]{2}{*}{ Sig. } & \multicolumn{2}{|c|}{ Collinearity Statistics } \\
\hline & & $\mathrm{B}$ & Std. Error & & & & Tolerance & VIF \\
\hline \multirow[t]{5}{*}{1} & (Constant) & 3.748 & 1.498 & & 2.502 & .014 & & \\
\hline & $\mathrm{AKO}$ & -.101 & .080 & -.114 & -1.263 & .209 & .891 & 1.123 \\
\hline & $\overline{\mathrm{AKI}}$ & .033 & .089 & .033 & .374 & .709 & .934 & 1.070 \\
\hline & $\mathrm{AKP}$ & .047 & .081 & .050 & .577 & .565 & .964 & 1.037 \\
\hline & $\overline{\mathrm{LA}}$ & -.104 & .083 & -.111 & -1.265 & .208 & .948 & 1.055 \\
\hline
\end{tabular}

*corresponding authors e-mail : lailazulviana@student.untan.ac.id

Online ISSN: 2721-4230 | Print ISSN: 2721-4281

DOI : http://dx.doi.org/10.26418/ejme.v8i4.43668 
PENGARUH KANDUNGAN INFORMASI KOMPONEN LAPORAN ARUS KAS, LABA AKUNTANSI DAN SIZE PERUSAHAAN TERHADAP RETURN SAHAM PADA PERUSAHAAN CONSUMER GOOD DI BURSA EFEK INDONESIA

Laila Zulviana a, ................ b, ............ c

\begin{tabular}{|l|r|r|r|r|r|r|r|}
\hline SP & .646 & .162 & .377 & 3.984 & .000 & .813 & 1.230 \\
\hline
\end{tabular}

a. Dependent Variable: RS

$$
\text { Sumber : Hasil Olahan SPSS (2018) }
$$

Berdasarkan tabel di atas dapat disimpulkan bahwa arus kas operasi, arus kas investasi, arus kas pendanaan, laba akuntansi dan size perusahaan memiliki nilai tolerance $>0,10$ dan nilai VIF $<10$. Dengan demikian variabel independen yang digunakan dalam penelitian ini model regresi penelitian adalah terbebas dari multikolineritas. Sehingga aman untuk dilanjutkan dengan uji hipotesis penelitian.

Tabel Hasil Uji Heteroskedastisitas

\begin{tabular}{|c|c|c|c|c|c|c|c|c|}
\hline & & & AKO & AKI & AKP & SP & LA & $\begin{array}{l}\text { Unstandardi } \\
\text { zed Residual }\end{array}$ \\
\hline \multirow[t]{17}{*}{$\begin{array}{l}\text { Spearman's } \\
\text { rho }\end{array}$} & \multirow[t]{3}{*}{ AKO } & $\begin{array}{l}\text { Correlation } \\
\text { Coefficient }\end{array}$ & 1.000 & .131 & .055 & -.078 & .031 & -.007 \\
\hline & & Sig. (2-tailed) & & .155 & .553 & .397 & .733 & .937 \\
\hline & & $\bar{N}$ & 120 & 120 & 120 & 120 & 120 & 120 \\
\hline & \multirow[t]{3}{*}{ AKI } & $\begin{array}{l}\text { Correlation } \\
\text { Coefficient }\end{array}$ & .131 & 1.000 & .044 & -.077 & -.012 & .009 \\
\hline & & Sig. (2-tailed) & .155 & & .632 & .402 & .898 & .920 \\
\hline & & $\mathrm{N}$ & 120 & 120 & 120 & 120 & 120 & 120 \\
\hline & \multirow[t]{3}{*}{ AKP } & $\begin{array}{l}\text { Correlation } \\
\text { Coefficient }\end{array}$ & .055 & .044 & 1.000 & -.140 & .026 & -.010 \\
\hline & & Sig. (2-tailed) & .553 & .632 & . & .127 & .774 & .915 \\
\hline & & $N$ & 120 & 120 & 120 & 120 & 120 & 120 \\
\hline & \multirow[t]{3}{*}{ SP } & $\begin{array}{l}\text { Correlation } \\
\text { Coefficient }\end{array}$ & -.078 & -.077 & -.140 & 1.000 & $.267^{\star \star}$ & -.036 \\
\hline & & Sig. (2-tailed) & .397 & .402 & .127 & & .003 & .700 \\
\hline & & $\mathrm{N}$ & 120 & 120 & 120 & 120 & 120 & 120 \\
\hline & \multirow[t]{3}{*}{$\overline{L A}$} & $\begin{array}{l}\text { Correlation } \\
\text { Coefficient }\end{array}$ & .031 & -.012 & .026 & $.267^{* \star}$ & 1.000 & .020 \\
\hline & & Sig. (2-tailed) & .733 & .898 & .774 & .003 & & .827 \\
\hline & & $N$ & 120 & 120 & 120 & 120 & 120 & 120 \\
\hline & \multirow[t]{2}{*}{$\begin{array}{l}\text { Unstandardized } \\
\text { Residual }\end{array}$} & $\begin{array}{l}\text { Correlation } \\
\text { Coefficient }\end{array}$ & -.007 & .009 & -.010 & -.036 & .020 & 1.000 \\
\hline & & Sig. (2-tailed) & .937 & .920 & .915 & .700 & .827 & \\
\hline
\end{tabular}

*corresponding authors e-mail : lailazulviana@student.untan.ac.id Online ISSN: 2721-4230 | Print ISSN: 2721-4281 DOI : http://dx.doi.org/10.26418/ejme.v8i4.43668 


\begin{tabular}{|l|l|r|r|r|r|r|r|}
\hline $\mathrm{N}$ & 120 & 120 & 120 & 120 & 120 & 120 \\
\hline
\end{tabular}

**. Correlation is significant at the 0.01 level (2-tailed).

Sumber : Hasil Olahan SPSS (2018)

Berdasarkan tabel di atas ke 5 variabel menunjukan nilai signifikansi atau sig. (2tailed) $>0,05$, pengujian yang baik yaitu tidak terjadinya heterokedastisitas diantara variabel independen yang diteliti. Maka dapat disimpulkan tidak terjadinya heteroskedastisitas. Artinya model regresi yang dipakai untuk penelitian ini layak digunakan.

\section{Uji Kelayakan Model Regresi Linier Berganda}

Tabel Hasil Regresi Linier Berganda

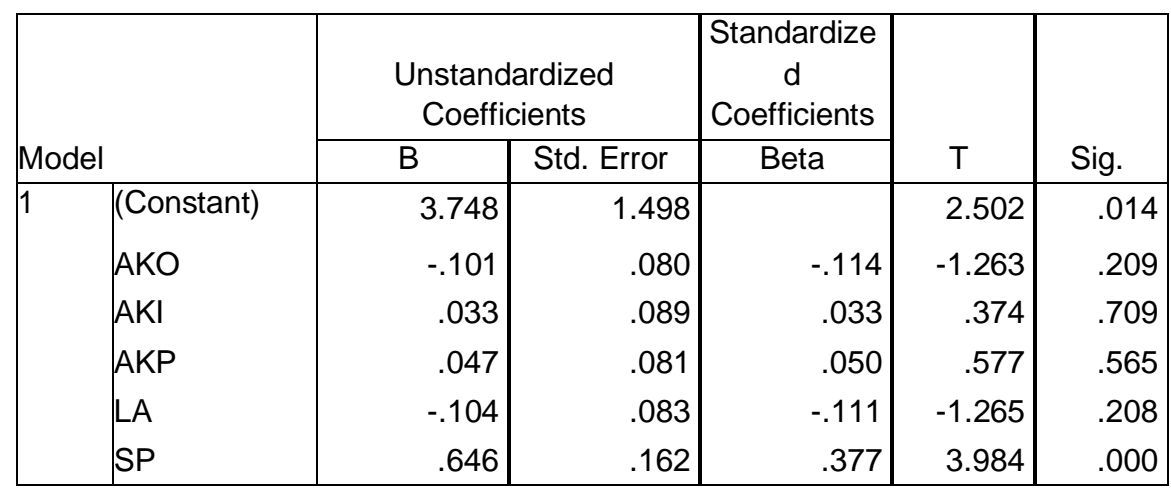

a. Dependent Variable: RS

Sumber : Hasil Olahan SPSS (2018)

Berdasarkan tabel di atas dapat diperoleh persamaan regresi linier berganda sebagai berikut :

\section{$\mathrm{RS}=3,748-0,101 \times 1+0,033 \mathrm{X} 2+0,047 \mathrm{X3}-0,104 \mathrm{X} 4+0,646 \mathrm{X5}+\mathrm{e}$}

Konstanta $=3,748$, artinya jika arus kas operasi, arus kas investasi, arus kas pendanaan, laba akuntansi dan size perusahaan nilainnya 0 maka, return saham nilainya positif sebesar 3,748 .

\section{Pengujian Hipotesis}

Pengujian hipotesis dalam penelitian ini menggunakan uji signifikan simultan parameter individual (uji statistik f), uji signifikansi parameter individual (uji statistik t), dan uji koefisien determinan (adjusted R2). 
Tabel Hasil Uji f

\begin{tabular}{|c|c|c|c|c|c|c|}
\hline \multicolumn{2}{|c|}{ Model } & $\begin{array}{l}\text { Sum of } \\
\text { Squares }\end{array}$ & Df & $\begin{array}{c}\text { Mean } \\
\text { Square }\end{array}$ & $F$ & Sig. \\
\hline \multirow[t]{3}{*}{1} & Regression & 55.763 & 5 & 11.153 & 4.614 & $.001^{b}$ \\
\hline & Residual & 275.582 & 114 & 2.417 & & \\
\hline & Total & 331.345 & 119 & & & \\
\hline
\end{tabular}

a. Dependent Variable: RS

b. Predictors: (Constant), SP, AKP, LA, AKI, AKO

Dari pengujian secara keseluruhan (simultan) maka diperoleh hasil seperti yang terlihat pada tabel di atas bahwa nilai signifikan dari 5 variabel tersebut adalah 0,001. Jika nilai signifikan $<0,05$ maka hipotesis ditolak (koefisien regresi signifikan). Ini berarti bahwa secara simultan Arus Kas Operasi, Arus Kas investasi, Arus Kas Pendanaan, Laba Akuntansi dan Size Perusahaan mempunyai pengaruh yang signifikan terhadap Return Saham.

Tabel Hasil Uji t

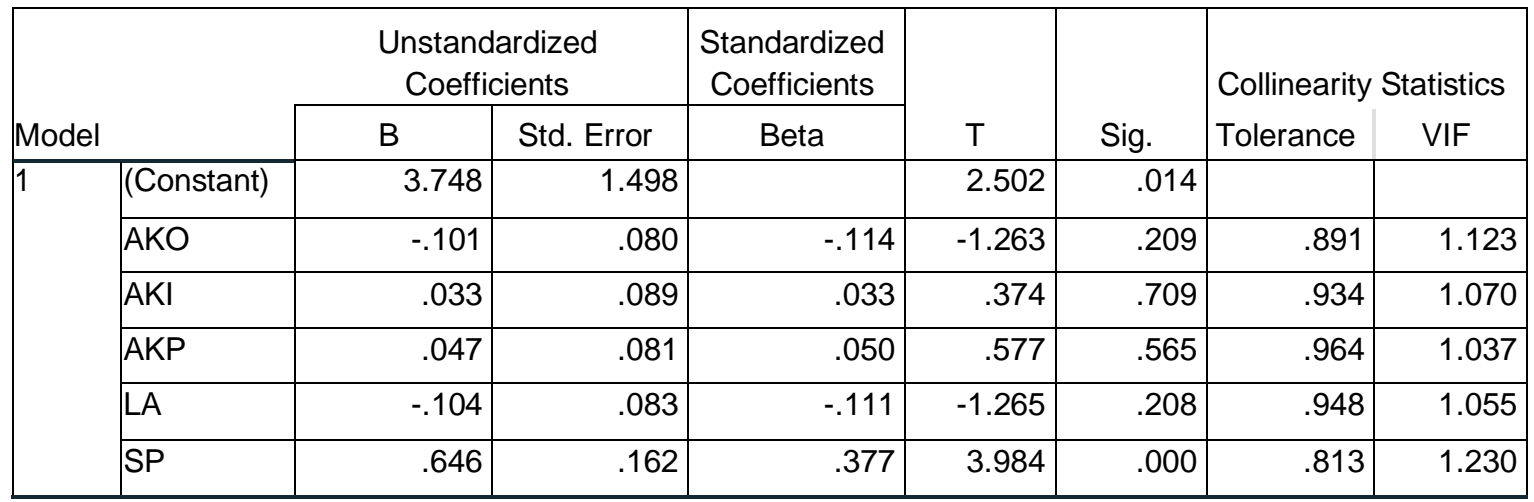

a. Dependent Variable: RS Sumber : Hasil Olahan SPSS (2018)

penelitian ini bertentangan dengan hasil penelitian oleh Mar'ati (2012) bahwa size perusahaan berpengaruh negatif dan tidak signifikan.

Tabel Hasil Uji R2

\begin{tabular}{|l|l|r|r|r|}
\hline Model & $\mathrm{R}$ & $\mathrm{R}$ Square & $\begin{array}{c}\text { Adjusted R } \\
\text { Square }\end{array}$ & $\begin{array}{c}\text { Std. Error of } \\
\text { the Estimate }\end{array}$ \\
\hline 1 & $.410^{\mathrm{a}}$ & .168 & .132 & 1.55479 \\
\hline
\end{tabular}

a. Predictors: (Constant), SP, AKP, LA, AKI, AKO

b. Dependent Variable: RS

Besarnya R2 berdasarkan analisis komputasi dengan program SPSS sebesar 0,168. Dengan demikian besarnya pengaruh Arus Kas Operasi (X1), Arus Kas Investasi ( X2 ), Arus Kas Pendanaan ( X3 ), Laba Akuntansi (X4), dan Size Perusahaan (X5) terhadap Return Saham secara bersama-sama atau secara simultan adalah sebesar 13,2\%. Sedangkan sisanya yaitu 100\% - 13,2\% $=86,8 \%$ adalah pengaruh atau sebab yang ditimbulkan oleh faktor lain yang tidak diteliti 
PENGARUH KANDUNGAN INFORMASI KOMPONEN LAPORAN ARUS KAS, LABA AKUNTANSI DAN SIZE PERUSAHAAN TERHADAP RETURN SAHAM PADA PERUSAHAAN CONSUMER GOOD DI BURSA EFEK INDONESIA

Laila Zulviana a, ................ b, ........... c

dalam penelitian ini. Diharapkan untuk penelitian selanjutnya perlu memperhatikan faktor lain yaitu laba kotor, ROA, dan ROE.

1. Arus kas operasi berpengaruh negatif dan tidak signifikan terhadap return saham

2. Arus kas investasi berpengaruh positif dan tidak signifikan terhadap return saham

3. Arus kas pendanaan berpengaruh positif dan tidak signifikan terhadap return saham

4. Laba akuntansi berpengaruh negatif dan tidak signifikan terhadap return saham

5. Size perusahaan berpengaruh positif dan signifikan terhadap return saham

6. Arus kas operasi, arus kas investasi, arus kas pendanaan, laba akuntansi dan size perusahaan secara simultan berpengaruh signifikan terhadap return saham

\section{SIMPULAN}

a. Uji t diperoleh nilai koefisien regresi untuk variabel arus kas operasi (AKO) sebesar -0,101 dengan nilai signifikansi sebesar 0,209, dimana nilai ini tidak signifikan pada tingkat signifikansi 0,05, karena lebih besar dari 0,05. Ini berarti bahwa secara parsial arus kas operasi berpengaruh negatif dan tidak signifikan terhadap return saham pada perusahaan consumer goods di BEI tahun 2014-2017. Hasi penelitian ini menunjukkan bahwa koefisien negatif artinya tidak terjadi hubungan satu arah antara arus kas operasi dan return saham, dan juga arus kas operasi tidak dapat mempengaruhi minat para investor karena perusahaan tidak dapat menghasilkan arus kas yang cukup untuk melunasi pinjaman, memelihara kemampuan operasi perusahaan, membayar dividen, dan melakukan investasi baru tanpa mengandalkan sumber pendanaan dari luar.

b. Uji t diperoleh nilai koefisien regresi untuk variabel arus kas investasi (AKI) sebesar 0,033 dengan nilai signifikansi sebesar 0,374 dimana nilai ini tidak signifikan pada tingkat signifikansi pada tingkat signifikansi 0,05, karena lebih besar dari 0,05. Ini beararti bahwa secara parsial arus kas investasi berpengaruh positif dan tidak signifikan terhadap return saham pada perusahaan consumer goods di BEI tahun 2014-2017. Hasil penelitian ini menunjukkan bahwa koefisien positif artinya terjadi hubungan satu arah antara arus kas invsetasi dan return saham, dan juga arus kas investasi tidak dapat mempengaruhi minat para investor untuk tertarik membeli saham perusahaan karena nilai arus kas investasi tidak signifikan atau tidak tepat untuk dijadikan bahan analisis oleh investor sehingga mengurangi permintaan terhadap return saham berada pada posisi tetap atau menurun. Dan apabila arus kas investasi dalam perusahaan menurun, berarti perusahaan tidak menjual aktiva tetap

*corresponding authors e-mail : lailazulviana@student.untan.ac.id Online ISSN: 2721-4230 | Print ISSN: 2721-4281 DOI : http://dx.doi.org/10.26418/ejme.v8i4.43668 
c. Uji t diperoleh nilai koefisien regresi untuk variabel arus kas pendanaan (AKP) sebesar 0,047 dengan nilai signifikansi sebesar 0,565 dimana nilai ini tidak signifikan pada tingkat signifikansi 0,05, karena lebih besar dari 0,05. Ini berarti bahwa secara parsial arus kas pendanaan berpengaruh positif dan tidak signifikan terhadap return saham pada perusahaan consumer goods di BEI tahun 2014-2017. Hasil penelitian ini menunjukkan bahwa koefisien positif artinya terjadi hubungan satu arah antara arus kas pendanaan dan return saham, dan juga arus kas pendanaan tidak dapat mempengaruhi minat para investor untuk tertarik membeli saham perusahaan yang bersangkutan karena nilai arus kas pendanaan tidak signifikan atau tidak tepat untuk dijadikan bahan untuk dianalis oleh investor sehingga mengurangi permintaan terhadap return saham berada pada posisi tetap atau menurun.

d. Uji t diperoleh nilai koefisien regresi untuk variabel laba akuntansi (LA) sebesar -0,104 dengan nilai signifikansi sebesar 0,208 dimana nilai ini tidak signifikan pada tingkat signifikansi 0,05 , karena lebih besar dari 0,05. Ini berarti bahwa secara parsial laba akuntansi berpengaruh negatif dan tidak signifikan terhadap return saham pada perusahaan consumer goods di BEI tahun 2014-2017. Hasil penelitian ini menunjukkan bahwa koefisien negatif artinya tidak terjadi hubungan satu arah antara laba akuntansi dan return saham, dan juga laba akuntansi tidak dapat mempengaruhi minat para investor hal ini dikarenakan investor melihat laba akuntansi yang berfluktuasi atau tidak konsisten dalam menghasilkan laba untuk memenuhi imbalan kepada para investor seperti memberikan deviden atau return kepada investor, sehingga investor akan melihat laporan keuangan yang lain sebagai bahan untuk dianalisis dalam berinvestasi dan laporan laba akuntansi tidak dapat meningkatkan permintaan terhadap return saham.

e. Uji t diperoleh nilai koefisien regresi untuk variabel size perusahaan (SP) sebesar 0,646 dengan nilai signifikansi sebesar 0,000 dimana nilai ini signifikan pada tingkat signifikansi 0,05, karena lebih kecil dari 0,05. Ini berarti bahwa size perusahaan berpengaruh positif dan signifikan terhadap return saham pada perusahaan consumer goods di BEI tahun 2014-2017. Hasil penelitian ini menunjukkan bahwa koefisien positif artinya terjadi hubungan satu arah antara size perusahaan dan return saham, dan juga size perusahaan yang berukuran besar akan memiliki lebih banyak aktiva dan memiliki prospek yang baik dalam jangka waktu relatif lama, sehingga perusahaan-perusahaan besar akan cenderung beroperasi pada tingkat yang maksimal, dengan demikian hal ini akan mempengaruhi minat para investor untuk membeli saham perusahaan dan akan meningkatkan return saham.

f. Uji f diperoleh nilai signifikan dari 5 variabel tersebut adalah 0,001. Jika nilai signifikan $<0,05$ maka hipotesis diterima. Ini berarti bahwa secara simultan Arus Kas Operasi, Arus Kas investasi, Arus Kas Pendanaan, Laba Akuntansi 
PENGARUH KANDUNGAN INFORMASI KOMPONEN LAPORAN ARUS KAS, LABA AKUNTANSI DAN SIZE PERUSAHAAN TERHADAP RETURN SAHAM PADA PERUSAHAAN CONSUMER GOOD DI BURSA EFEK INDONESIA

Laila Zulviana a, ................ b, ........... c

dan Size Perusahaan mempunyai pengaruh yang signifikan terhadap Return Saham.

\section{REKOMENDASI}

Penelitian ini memberikan beberapa saran atau rekomendasi sebagai berikut :

a. Hasil penelitian ini diharapkan Investor yang ingin berinvestasi pada perusahaan consumer goods hendaknya lebih memperhatikan informasi mengenai size perusahaan karena semakin besar size perusahaan berarti semakin tinggi pula kepercayaan investor ini akan meningkatkan permintaan saham dan pada akhirnya akan meningkatkan harga saham dan juga return saham, dengan tetap memperhatikan arus kas operasi, arus kas investasi, arus kas pendanaan dan laba akuntansi perusahaan walaupun dalam penelitian ini tidak terdapat pengaruh signifikan bagi return saham.

b. Bagi Peneliti selanjutnya diharapkan diharapkan untuk menambah variabel variabel baru sehingga dengan adanya variabel baru akan membuat temuan baru yang lebih baik dan bermanfaat. Variabel yang dimaksudkan seperti laba kotor, ROA dan ROE. Juga diharapkan untuk menambah sampel perusahaan lainnya atau dengan kata lain memperluas sampel penelitian.

\section{KETERBATASAN PENELITIAN}

Keterbatasan dalam penelitian ini ditemukan bahwa adjusted R2 yang diteliti hanya berpengaruh sebesar $13,2 \%$ ini menunjukan bahwa pengaruh arus kas operasi, arus kas investasi, arus kas pendanaan, laba akuntansi dan size perusahaan terhadap return saham masih sangat sedikit dibanding faktor-faktor lain yaitu sebesar $86,8 \%$ dipengaruh oleh faktor lain yang dapat diteliti selanjutnya. Diharapkan untuk penelitian selanjutnya perlu memperhatikan faktor lain seperti laba kotor, ROA dan ROE. 
PENGARUH KANDUNGAN INFORMASI KOMPONEN LAPORAN ARUS KAS, LABA AKUNTANSI DAN SIZE PERUSAHAAN TERHADAP RETURN SAHAM PADA PERUSAHAAN CONSUMER GOOD DI BURSA EFEK INDONESIA

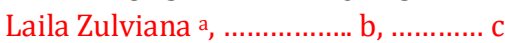

\section{DAFTAR RUJUKAN}

Adiwiratama, Jundan. 2012. Pengaruh Informasi Laba, Arus Kas dan Size Perusahaan Terhadap Return Saham (Studi Empiris Pada Perusahaan Manufaktur Yang Terdaftar Di BEI), Rurnal Ilmiah Akuntansi dan Humanika JINAH. Vol 2 No 1 Desember 2012 ISSN 20893310.

Arista dan Astohar. 2012 . Analisis Laporan Keuangan Konsep dan Aplikasi, Yogyakarta :UPP STIM YKPN.

Ball, R and P. Brown. 1968. An Empirical Evaluation of Accounting Income Number. Journal of Accounting Research 6: 159-178.

Brigham, F Eugene dan Joel F Houston. 2011. Dasar-Dasar Manajemen Keuangan. Buku 1 Edisi 10. Jakarta: Selemba Empat.

Chan, Chen, N.-f., \& HSIEH, D. A. (2005). An Exploratory Investigation of The Firm Size Effect. Journal of Financial Economics 14, 451-471.

Ginting, Suriani. 2012 . Analisis Pengaruh Pertumbuhan Arus Kas dan Profitabilitas Terhadap Return Saham Pada Perusahaan LQ 45 di Bursa Efek Indonesia, Jurnal Wira Ekonomi Mikroskil , Volume 2, Nomor 01, April.

Ghozali, Imam. 2013. Aplikasi Analisis Multivariat dengan SPSS.Semarang: Universitas Dipenegoro.

Ghozali, Imam. 2006. Analisis multivariate dengan Program SPSS. Edisi Keempat. Badan Penerbit Fakultas Ekonomi Universitas Diponegoro, Semarang.

Harahap. 2010. Teori Akuntansi Edisi Revisi. Jakarta: Raja Grafindo Persada.

Harahap. 2011. "Teori Akuntansi - Edisi Revisi 2011". Jakarta. PT Rajagrafindo Persada. Hertsediandani, Aprenia. 2017. "Pengaruh Perubahan Laba Dan Arus Kas Terhadap Return Saham

Pada Perusahaan Manufaktur Yang Terdaftar Di BEI" Sekolah Tinggi Ilmu Ekonomi Perbanas Surabaya.

Ibrahim, Hadiasman. 2008. Pengaruh Tingkat Suku Bunga, Peringkat Obligasi, Ukuran Perusahaan Dan Der Terhadap Yield To Maturity Obligasi Korporasi Di Bursa Efek Indonesia Periode Tahun 2004-2006. Tesis Program Studi Magister Manajemen Program Pasca Sarjana Universitas Diponegoro, Semarang.

Ikatan Akuntan Indonesia. 2012a. Standar Akuntansi Keuangan. Jakarta: Salemba Empat. 
PENGARUH KANDUNGAN INFORMASI KOMPONEN LAPORAN ARUS KAS, LABA AKUNTANSI DAN SIZE PERUSAHAAN TERHADAP RETURN SAHAM PADA PERUSAHAAN CONSUMER GOOD DI BURSA EFEK INDONESIA

Laila Zulviana a, ............... b, ........... c

Ikatan Akuntan Indonesia. 2012b. Pernyataan Standar Akuntansi Keuangan Indonesia (PSAK). Jakarta: IAI.

Kartikahadi, Hans. 2012. Akuntansi Keuangan Berdasarkan SAK Berbasis IFRS. Salemba Empat: Jakarta

Mackenzie, Bruce, Alland Lombard, dan Danie Coestsee. 2012. IFRS for SMEs. Jakarta : Indeks.

Marwata, 2011, Pengaruh Faktor Fundamental Perusahaan dan Nilai Tukarterhadap Return Saham pada Perusahaan yang Terdaftar di BEI(Kasus pada Perusahaan Manufaktur Periode Tahun 2003 - 2007). Tesis, Program Pasca Sarjana Magister Manajemen Universitas Diponegoro, Semarang. (tidak dipublikasikan).

Mar’ati, Fudji Sri. 2013. “Pengaruh Laba Akuntansi Dan Arus Kas Terhadap Return Saham”. Among Makarti. Vol. 2, No. 4, Desember.

Pratama Satria, dan Akbar Alfian Dinnul. 2014. Pengaruh Laba dan Komponen Arus Kas Terhadap Return Saham Pada Perusahaan Manufaktur yang Terdaftar di BEI. STIE MDP.

Putranto Dwi Ashari, dan Darmawan Ari. 2017. Pengaruh Ukuran Perusahaan, Provitabilitas, Leverage, dan Nilai Pasar Terhadap Return Saham Pada Perusahaan Petambangan yang Terdaftar di BEI.

Purwanti Sri, Masitoh Endang dan Chomsatu Yuli. 2015. Pengaruh Laba Akuntansi dan Arus Kas Terhadap Return Saham Perusahaan yang Listing di BEI, Jurnal Akuntansi dan Pajak VOL. 16 NO. 01, JULI 2015 - 113 ISSN : 1412$629 \mathrm{X}$.

Putra, Dwi, Gunartha, Made, I dan Dana Made I. 2015. “ Pengaruh Profitabilitas, Leverage, Likuiditas, Ukuran Perusahaan Terhadap Return Saham " Fakultas Ekonomi Dan Bisnis Universitas Udaya, Bali.

Rachmawati, Ria. 2016. "Pengaruh Arus Kas Operasi Dan Laba Akuntansi Terhadap Return Saham" Jurnal Akuntansi VOL 1, No 2-2016.

Rahmasari, Risna. 2014. "Pengaruh Arus Kas : Operasi, Investasi, Pendanaan Serta Laba Akuntansi Return Saham Pada Perusahaan Makanan Dan Minuman Yang Terdaftar Di Bursa Efek Indonesia" Fakultas Ekonomi Universitas Muhammadiyah Purwokerto.

Samsul, Mohamad. 2006. Pasar Modal Dan Manajemen Portofolio. Surabaya : Erlangga. Sanusi. 2014. Metodologi Penelitian Bisnis. Jakarta: Salemba Empat. 
PENGARUH KANDUNGAN INFORMASI KOMPONEN LAPORAN ARUS KAS, LABA AKUNTANSI DAN SIZE PERUSAHAAN TERHADAP RETURN SAHAM PADA PERUSAHAAN CONSUMER GOOD DI BURSA EFEK INDONESIA

Laila Zulviana a, ................ b, ........... c

Simanungkalit, 2009, Pengaruh Profitabilitas dan Leverage Keuangan terhadap Return Saham, Skripsi, Semarang: Undip.

Subramanyam. 2010. Analisis laporan keuangan. Jilid satu dan dua. Jakarta: salemba empat.

Suhairi. 2006. Pengaruh Kandungan Informasi Komponen Laporan Arus Kas, Laba Kotor, dan Size Perusahaan Terhadap Expected Return Saham. Simposium Nasional Akuntansi IX: Padang.

Sugiyono. 2014. Metode Penelitian Bisnis. Bandung : Alfabeta.

Syakur. 2009. Intermediate Accounting dalam Perspektif yang Lebih Luas. Jakarta : Publishep.

Tagor. 2008. Pengaruh ukuran perusahaan, leverage, price earning ratio dan profitabilitas terhadap nilai perusahaan. Jurnal Ilmu Manajemen, 1(1), 183-196

Tandelilin, Eduardus. 2010. Portofolio dan Investasi Teori dan Aplikasi, Edisi Pertama, Kanisus, Yogyakarta.

Triwuyono. 2013. Metodologi dan Teori Akuntansi. Jakarta : PT Raja Grafindo Persada

Tumbel Ayub Gilbert, Tinangon Jantje dan Walandow Kho Stanley. 2016. "Pengaruh Laba Akuntansi Dan Arus Kas Operasi Terhadap Return Saham Pada Perusahaan Manufaktur Sektor Industri Barang Konsumsi Yang Terdaftar Bursa Efek Indonesia" Jurusan Akuntansi, Fakultas Ekonomi Dan Bisnis Universitas Sam Ratulangi Manado.

Ulfah, Ruriana. 2011. Pengaruh Ukuran Perusahaan, Leverage, Economic Value Added, Return On Investment, Dan Earning Per Share Terhadap Return Saham Yang Diterima Pemegang Saham (Studi Empiris Pada Industri Makanan Dan Minuman Di Bursa Efek Indonesia)" Jurusan Akuntansi, Fakultas Ekonomi Dan Bisnis Universitas Islam Negeri Syarif Hidayatullah.

Utomo, Seno Jodi. 2011. "Analisis Pengaruh Arus Kas Operasi Dan Laba Akuntansi Terhadap Return Saham Perusahaan Manufaktur Di Bursa Efek Indonesia" Universitas Negeri Semarang. Semarang

Warsono, Sony bin Hardono, Ratna Candrasari dam Irene Natalia. 2013. Akuntansi Pengantar 1 Sistem Penghasil Informasi Keuangan Adaptasi IFRS. Yogyakarta: AB Publisher.

www.idx.co.id. 
PENGARUH KANDUNGAN INFORMASI KOMPONEN LAPORAN ARUS KAS, LABA AKUNTANSI DAN SIZE PERUSAHAAN TERHADAP RETURN SAHAM PADA PERUSAHAAN CONSUMER GOOD DI BURSA EFEK INDONESIA

Laila Zulviana $a, \ldots \ldots \ldots \ldots \ldots . . . . . b, \ldots \ldots \ldots . . . c$

Yocelyn, dan Christiawan. 2012." Analisis Pengaruh Perubahan Arus Kas Dan Laba Akuntansi Terhadap Return Saham pada Perusahaan Berkapitalisasi Besar". Jurnal Akuntansi dan Keuangan. Vol. 14, No. 2, November, Hlmn 8190 . 